\title{
Reiteration of Projects and Scheduling with Cost Optimization
}

\author{
S. Vinothkumar, C. Anish, S. Venkatraman, K. Sathish Kumar
}

\begin{abstract}
Greater part of true redundant activities in development can be named Non-Typical. The variety of a movement length starting with one monotonous unit then onto the next can by and large be credited to varieties in the amounts of work as well as team efficiency variety starting with one unit then onto the next and additionally climate sway. Compelling arranging and planning of dreary ventures requires team work congruity. The principle target of work progression is the amplification of asset use by giving an asset driven timetable that keeps away from group perfect time. The greater part of the procedures grew so far arranging and booking of redundant ventures expected that each monotonous action will have a consistent length at all stages. The reason for this venture work is to display another definition going around the confinements of existing strategies as those programming methods concentrated on limiting task length and didn't represent its effect on the general expense. The calculation framed is utilized to decide the ideal team development for each dull movement that yields the base generally cost of the undertaking material to both common and non-run of the mill redundant ventures.
\end{abstract}

Keywords: amplification, monotonous action, Non-Typical

\section{INTRODUCTION}

\section{A. General}

Repetitive projects consists of a number of similar or identical units. Ex: Housing projects, pipe line network, Highway projects etc., This class of projects are also referred to as linear projects. These projects are divided in to 2 categories:

1.Typical :- Repetitive activities have identical durations in all units

Ex: Housing projects, where the same set of activities performed in constructing a typical house is repeated in all housing units within the project.

2. Non-Typical :- Repetitive activities do not have identical durations[1]-[5]

Revised Manuscript Received on October 22, 2019.

S.Vinothkumar, Assistant Professor, Department Of Civil Engineering,,Bharath Institution of Higher Education And Research,TamilNadu, India Email vinothsenna@gmail.com

C.Anish, Assistant Professor,,Department Of Civil Engineering,,Bharath Institution Of Higher Education And Research,TamilNadu, India .Email: anishdavidpaul@gmail.com

S.Venkatraman, Asistant Professor, Department Of Civil Engineering,,Bharath Institution of Higher Education And Research,TamilNadu, India Email: vinothsenna@gmail.com

K.Sathish Kumar, Asistant Professor, Department Of Civil Engineering,,Bharath Institution of Higher Education And Research,TamilNadu, India Email: sathish_4549@yahoo.co.in
Ex: Highway construction, where the time required for excavation may vary from one section to another.

Successful arranging and booking of dreary ventures requires team work coherence. This limitation for a given group can be kept up by guaranteeing team smooth development starting with one dull unit then onto the next without interferences. The primary goal of work congruity is the amplification of asset usage by giving an asset driven calendar that maintains a strategic distance from team perfect time.

\section{OBJECTIVE}

-At the point when looked with the ventures including numerous redundant exercises, the majority of which have their very own arrangements of conceivable group developments, the difficult standing up to the organizer is, which is the ideal team arrangement for each monotonous movement that yields the base generally speaking expense of the venture?"

-The reason for this undertaking work is to show another detailing bypassing the constraints of existing systems as those procedures are centered around limiting task span and didn't represent its effect on the general expense.

-This may as a rule lead to higher by and large venture cost.

-The calculation framed in this venture work is utilized to decide the ideal team development for each dreary action that yields the base by and large cost of the undertaking relevant to both ordinary and non-regular monotonous activities[6]-[10]

\section{RESEARCH METHODOLOGY}

\section{A. Methodology}

The following flow chart is an example of explaining the methodology adopted in the project work to find out the optimum crew formation from the available crew formations using the present algorithm 


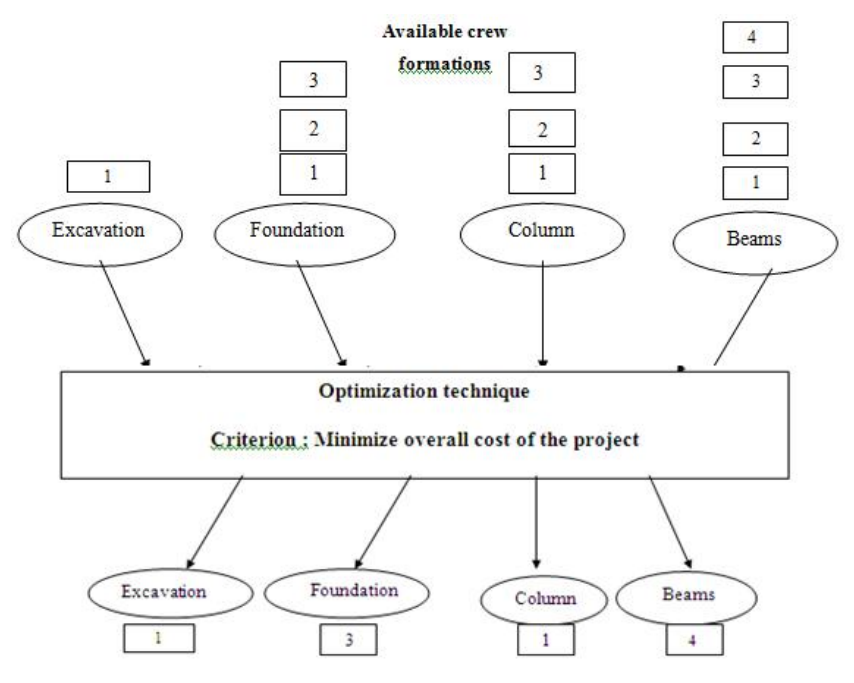

IV. RESULT \& DISCUSSION

\section{A. Model Calculations-Excavation}

\section{Calculation for Early start in Working Days}

Section 1

$$
=0 \text { day }
$$

Section 2

Section 3 :

$$
\begin{aligned}
= & \text { Quantity/Output } \\
= & 1147 \mathrm{~m}^{3} \\
& - \\
& 91.75 \mathrm{~m}^{3} / \text { day } \\
= & 12.5 \text { days }
\end{aligned}
$$

$$
\begin{aligned}
& 1434 \mathrm{~m}^{3} \\
= & ----------12.5 \\
= & 28.1 \text { days }
\end{aligned}
$$

Section 4:

$$
\begin{aligned}
& 994 \mathrm{~m}^{3} \\
= & -------------+28.1 \\
= & 39 \text { days }
\end{aligned}
$$

Finish :

$$
\begin{aligned}
& \frac{1529 \mathrm{~m}^{3}}{91.75 \mathrm{~m}^{3} / \text { day }} \\
= & 55.6 \text { days }
\end{aligned}
$$

\section{B. Cost Calculations: ( Excavation )}

Indirect Cost is assumed to be Rs.40,000 / day which includes Office expenses, Project miscellaneous expenses, Penalties etc.,

$$
\begin{aligned}
& \text { Indirect Cost } \quad=55.6 \times 40,000 \\
& =\text { Rs. } 22,25,000 \\
& \text { Direct Cost }=\mathrm{MCn}^{\mathrm{i}} \cdot \mathrm{Qj}^{\mathrm{i}}+\mathrm{LCn}^{\mathrm{i}} \cdot \mathrm{Dnj}^{\mathrm{i}} \\
& +\mathrm{ECn}^{\mathrm{i}} \cdot \mathrm{Dnj}^{\mathrm{i}}=0 \times 0+13600 \times 55.6+22640 \times 22640 \\
& =\text { Rs. } 20,15,880 \\
& \text { Overall Cost }=\text { Indirect Cost }+ \text { Direct Cost } \\
& \text { = Rs. } 22,25,000+\text { Rs. } 20,15,880 \\
& \text { = Rs. 42,40,880 }
\end{aligned}
$$

The same procedure is repeated for various items of work such as foundations, columns, beams and slabs and the same calculations are repeated for different crew formations with the help of MS - Excel Spread sheet

Table- Input Data

\begin{tabular}{|c|c|c|c|c|}
\hline \multirow{2}{*}{$\begin{array}{c}\text { Repetitive } \\
\text { activity }\end{array}$} & \multicolumn{4}{|c|}{ Quantities in cubic meter } \\
\cline { 2 - 5 } & Section l & Section 2 & Section 3 & Section 4 \\
\hline Excavation & 1147 & 1434 & 994 & 1529 \\
\hline Foundation & 1032 & 1077 & 943 & 898 \\
\hline Columns & 104 & 86 & 129 & 100 \\
\hline Beams & 85 & 92 & 101 & 80 \\
\hline Slabs & 0 & 138 & 114 & 145 \\
\hline
\end{tabular}

\section{Comparison of Results}

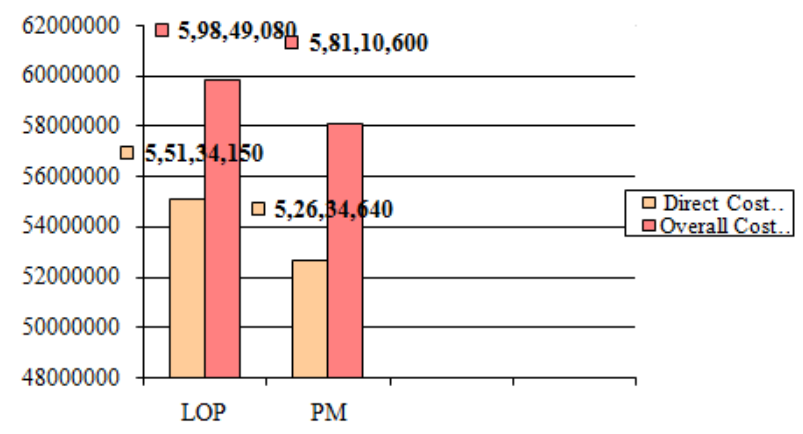

LOP - LOCAL OPTIMIZATION PROBLEM

\section{LOCAL OPTIMIZATION PROBLEM}

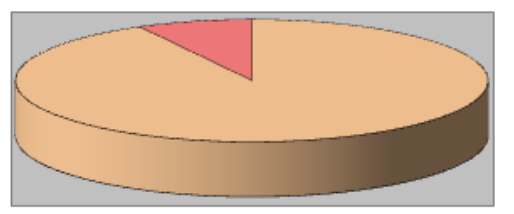

口DC- 5.5crores IDC- 0.47 crores 


\section{IDC - INDIRECT COST COMPARISON FOR DURATION OF COMPLETION IN DAYS}

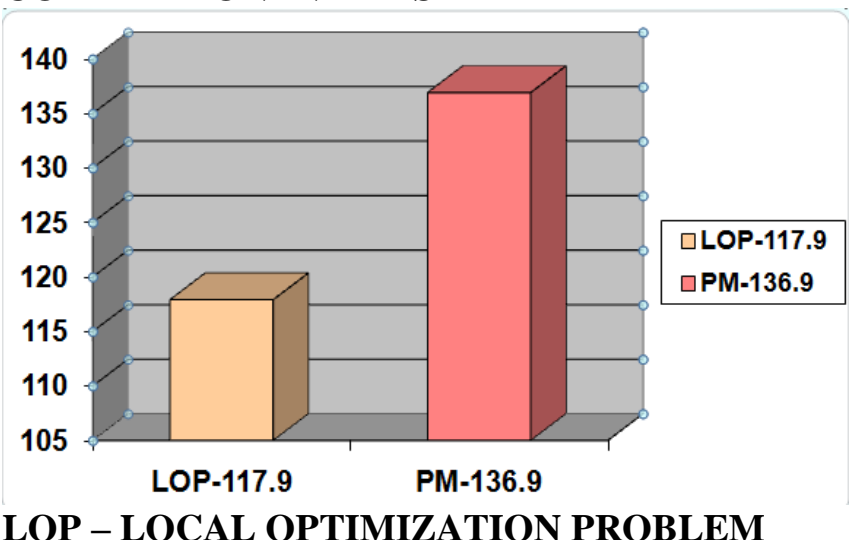

PM - PROPOSED MODEL

\section{CONCLUSIONS}

Based on the study involved so far, the following conclusion have been drawn.

- An calculation was created to decide the ideal group arrangement so as to limit team inert time and keep up work progression with the goal that the general expense of the venture will be limited.

- Even however the task span expands the general expense of the undertaking was limited by keeping up group work coherence

- This calculation model demonstrate helpful to proprietors and contractual workers the same, and add to practical conveyance of developed undertaking[11]-[13]

\section{REFERENCES}

1. Sathish Kumar, K., Vinothkumar, S., Venkatakrishnaiah, R. \& Mohan, S.J. 2019, "Experimental investigation on rehabilitation of corroded concrete beam specimens", International Journal of Civil Engineering and Technology, vol. 10, no. 1, pp. 2949-2955.

2. Kanchanabhan, T.E., Krishnaiah, R.V., Dayakar, P. and Mani, A., 2019. A detailed study on green building concept in construction industry. International Journal of Civil Engineering and Technology, 10(1), pp. 2944-2948.

3. Mugilvani, P., Murugan, S.T., Kaviya, B. and Sathishkumar, K., 2019. Experimental investigation on nano concrete. International Journal of Civil Engineering and Technology, 10(1), pp. 907-912.

4. Vinothkumar, S., Sathishkumar, K., Anish, C. and Rajesh, S., 2019. Characteristic strength of concrete by partial replacement with sawdust and waste ceramic tiles. International Journal of Civil Engineering and Technology, 10(1), pp. 2821-2829.

5. Chitra, R., Thendral, S., Arunya, A. and Mohan, S.J., 2019. Experimental study on strength of concrete by partial replacement of fine aggregate with saw dust. International Journal of Civil Engineering and Technology, 10(1), pp. 2766-2769.

6. Mani, A., Meikandaan, T.P., Gowrishankar, P.G. and Kanchanabhan, T.E., 2019. A study on treatment of industrial effluent (dyeing) using moringa oleifera, tamarina indica as coagulants. International Journal of Civil Engineering and Technology, 10(1), pp. 2796-2811.

7. Frank Stephen, S., Chockalingam, M.P., Nalanth, N. and Lekshmy Raghavan, P., 2019. Study on the fresh state properties of self

compacting concrete modified with recycled concrete aggregate. International Journal of Civil Engineering and Technology, 10(1), pp. 1205-1212.

8. Dayakar, P., Raman, K.V., Arunya, A. and Venkatakrishnaiah, R., 2019. Study on strength properties of sand by biocementation with eggshell. International Journal of Civil Engineering and Technology, 10(1), pp. 2770-2785.

9. Shendge, R.B., Chockalingam, M.P., Saritha, B. and Ambica, A., 2018. Swat modelling for sediment yield: A case study of Ujjani reservoir in Maharashtra, India. International Journal of Civil Engineering and Technology, 9(1), pp. 245-252.

10. Meikandaan, T.P. and Hemapriya, M., 2017. Use of glass FRP sheets as external flexural reinforcement in RCC Beam. International Journal of Civil Engineering and Technology, 8(8), pp. 1485-1501.

11. Harini, A.T., 2017. Experimental study on utilisation of ceramic wastes in concrete. International Journal of Civil Engineering and Technology, 8(8), pp. 1346-1352.

12. Ambica, A., Sartiha, B. and Anbarasan, R., 2017. Groundwater quality assessment using water quality index and GIS, Maduravoyal, Chennai, India. International Journal of Civil Engineering and Technology, 8(8), pp. 1375-1381.

13. Aswathy, M., Saritha, B. and Chockalingam, M.P., 2019 Degradation of anionic dye using $\mathrm{Fe} / \mathrm{Tio} 2$ composite by photocatalysis. International Journal of Innovative Technology and Exploring Engineering, 8(9 Special Issue 3), pp. 788-791

\section{AUTHORS PROFILE}

Of
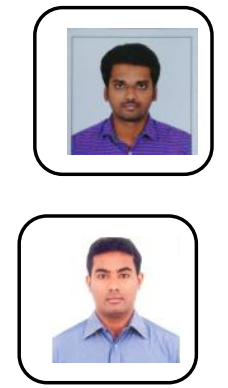

C.Anish, Assistant Professor,,Department Of Civil Engineering,,Bharath Institution Of Higher Education And Research,TamilNadu, India

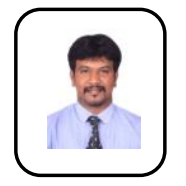

S.Venkatraman, Asistant Professor, Department Of Civil Engineering,,Bharath Institution of Higher Education And Research,TamilNadu, India

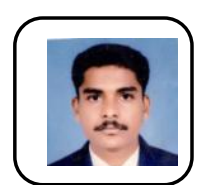

K.Sathish Kumar, Asistant Professor, Department Of Civil Engineering,,Bharath Institution of Higher Education And Research,TamilNadu, India Email: sathish_4549@yahoo.co.in 